DOI 10.37882/2223-2982.2020.06.37

\title{
ИСТОРИЯ ДОПОЛНИТЕЛЬНОГО ОБРАЗОВАНИЯ ДЕТЕЙ В РОССИИ
}

\section{HISTORY OF ADDITIONAL EDUCATION OF CHILDREN IN RUSSIA}

Qiao Lanju

Summary: the article is devoted to the history of additional education of children in Russia. the historical retrospective of changes in the organizational forms and content of additional education of children is traced. It is determined that in order to understand modern issues of additional education for children and identify its priorities for further improvement, it is necessary make sense of its history.

Keywords: additional education of children, extracurricular work, extracurricular education, historical experience.
Д ополнительное образование детей носит преемственный и исторически определённый характер. Актуальность вопроса дополнительного образодетей, в настоящее время является очевидной, поскольку она прямо связана с новым пониманием сути образования детей. Дополнительное образование детей анализируется как основная составляющая образовательного пространства, формирование которого, на основе тщательно обдуманных требований, позволит поддержать и воспитать одаренных детей. Дополнительное образование детей социально востребовано, ввиду чего является объектом внимания, поддерживается обществом и государством, и определяется как организованная особым образом, устойчивая коммуникация, направленная на развитие мотивации формирующейся личности ребенка к творчеству и познанию. Организовываемое на основе внешкольных учреждений дополнительное образование выделяется ориентацией на поддержку и формирование мотивации и самовыражения детей. Эти особенности вырабатывают среду личностного формирования и самовыражения ребенка. В этой связи, в основе дополнительного образования заложено понимание становления личности, как неотъемлемая часть интеллектуального и физического развития детей.

Современная область дополнительного образования детей России является продолжательницей системы внешкольной работы и образования с детьми, что определяет необходимость постижения жизненных изменений в общей истории ее формирования. Исторический анализ становления системы дополнительного образования детей разрешает констатировать, что к настояще-

\author{
Цяо Ланьцзюуй \\ Старший преподаватель, Харбинский Педагогический \\ Университет (КНP) \\ qiaolanju@gmail.com
}

Аннотация: Статья посвящена истории дополнительного образования детей в России, прослежена историческая ретроспектива изменения организационных форм и содержания дополнительного образования детей. Определено, что для понимания современных вопросов дополнительного образования детей и выявления его приоритетов для дальнейшего совершенствования необходимо осмыслить его историю.

Ключевые слова: дополнительное образование детей, внешкольная работа, внешкольное образование, исторический опыт.

му времени не сложились единые представления о его формировании и становлении. Следует отметить, что дополнительное образование (как вид образовательной деятельности) возникло в III- II тыс. до н.э. в Китае, Древней Греции, Древнем Риме, Индии и др. Уникальный опыт функционирования государственной системы дополнительного образования накоплен в России. Вопросы дополнительного образования подвергаются анализу в трудах разных исследователей (В.А. Березиной, В.П. Голованова, А.В. Золотаревой, Л.Ю. Кругловой, Е.В. Смольникова, М.О. Чекова и др.) [4]. Выделяют несколько этапов в формировании дополнительного образования детей. Рассмотрим их.

Первым этапом считаются 1905-1917 гг. Следует отметить, что в России историческим началом внешкольного воспитания считается XVII В. и связано это с возникновением «школьных товариществ». Одним из первых форм дополнительного образования рассматривается детский домашний театр, возникнувший в дворянских семьях России в конце XVIII в. Организационное формирование внешкольных форм работы относится к началу XX в. Основной задачей дополнительного образования того времени (у истоков которого стояли С.Т. Шацкий, А.У. Зеленко, К.А. Фортунатов, П.Ф. Лесгафт, К.Н. Вентцель), считалось формирование личности ребенка, воспитание у него ответственности и солидарности. Функциями дополнительного образования (до 1917 г.) считались образовательная и культурно-досуговая. Деятельность во внешкольных учреждениях строилась на принципах детского самоуправления.

Второй этап - 1918-1939 гг. На государственном уров- 
не решение о развитии внешкольного образования было принято в ноябре 1917 г. В Народном комиссариате просвещения РСФСР был создан отдел внешкольного образования. В период после революции С.Т. Шацким была открыта первая опытная станция по народному образованию. Концепция С.Т. Шацкого содержала идею «открытой» школы. Дополнительное (внешкольное образование) включили в общую систему народного просвещения. С июня 1918 г. начинается деятельность, организованная молодым биологом Б.В. Всесвятским, Станции юных любителей природы (с 1920 года - Биологической станции юных натуралистов) - первого государственного учреждения внешкольной работы с детьми [6].

В июне 1919 года был проведён I Всероссийский съезд по внешкольному образованию. В дальнейшем (1920-1930-е гг.) началось создание государственной системы внешкольных учреждений и дополнительное образование стало рассматриваться как часть коммунистического воспитания. Стали возникать первые научнометодические центры и новые внешкольные государственные детские учреждения. Е.Н. Медынским в 1923 г. была издана «Энциклопедия внешкольного образования» [9].

В этот период развития, дополнительное (внешкольное образование) приобретает следующие направления: социальная активность детей и подростков, получение детьми знаний, повышение общего культурного уровня, ликвидация неграмотности.

Главными функциями считаются преодоление и профилактика безнадзорности, занятия в данных учреждениях возмещали отсутствие у детей школьного образования, инструктивно-методические, организационно-массовые.

К формам организации внешкольных форм работы относились - клубы, отряды, станции, базы, театры, Дома пионеров. Довольно широко было распространено театральное искусство, художественное воспитание, экскурсионно-туристская работа. В структуре внешкольных учреждений появились общественные и педагогические советы (по идейно-политическому воспитанию; репертуарные советы; методические советы; шефские советы и др.). Была укреплена материальная база, данных учреждений, расширен аппарат управления, методы и принципы управления.

К третьему этапу относятся 1940-1960 гг. К данному времени сложилась широкая сеть внешкольных детских учреждений. Внешкольные учреждения уже состоят на бюджете органов народного образования. Строятся помещения, готовятся профессиональные кадры.
Важнейшими функциями дополнительного (внешкольного образования) этого периода были воспитательная, профессиональное и гражданское самоопределение детей; коммуникативная и социальная функции.

Содержание данной деятельности включала обучение учителей, руководителей кружков внешкольных учреждений, организация для детей практикумов, тематических чтений, внедрение опыта комсомольской, пионерской и внешкольной работы.

В период 1940-1970-х годов усиливается ведомственный подход в организации дополнительного образования, культурно-досуговая, оздоровительная работа с детским населением. В этот период довольно широко развивается деятельность детских здравниц и пионерских лагерей.

В организационной структуре данных учреждений сформировались методические центры, с тремя основными направлениями деятельности - инструктивно-методические, культурно-массовые. Однако следует также отметить, что формирование внешкольных учреждений тормозилось имеющейся нормативной базой, функционирующими финансово-экономическими механизмами и командно-административным стилем управления. Очевидной стала необходимость проведения преобразований и принятия комплекса радикальных мер, которые бы содействовали увеличению самостоятельности в решении существенных для учреждений вопросов, предоставляя им финансовую и хозяйственную самостоятельность.

1961-1986 гг. считаются расцветом и четвертым периодом становления дополнительного образования в России. В данное время создаются специализированные внешкольные детские учреждения. Эти учреждения дифференцируются, учитывая интересы детей. Возникают детские театры, ансамбли, развиваются разные направления массовой работы (ярмарки, конкурсы, праздники, акции) [15].

В 1980-х дополнительное образование освобождается от строгой регламентации. Внешкольным учреждениям возвращают право самостоятельно разработать программу своей деятельности, определять свою структуру, численность педагогических штатов и детских коллективов.

Содержание и форма работы в внешкольных учреждениях представляло оригинальную общность детей и взрослых, которая характеризовалась целенаправленностью и автономностью существования.

Период 1987-1992 гг. считается спадом и пятым этапом истории развития дополнительного образования. 
В государстве расходы на образование существенно уменьшились, резко сократилось количество и масштабы работы внешкольных учреждений. В 1991 г. распались пионерские и комсомольские организации, трансформируются прежние внешкольные ассоциации и движения, возникают новые [5].

Начиная с1993 г. по настоящее время, наблюдается стабилизация деятельности внешкольных учреждений и это считается шестым этапом.

Закон РФ от 10 июля 1992 г. N 3266-1«Об образовании» [2] внешкольным учреждениям вернул статус образовательных учреждений, тем самым основав правовые предпосылки для гуманистической, демократической системы образования. Данные учреждения получили название - учреждения дополнительного образования детей (УДОД). В дальнейшем вышло «Типовое положение об учреждении дополнительного образования» (1995 г.) [3]. Начиная с 1992 г. отмечается восстановление численности учреждений дополнительного образования, активизируется их деятельность.

Следует отметить, что уже с 1990-х гг. формируются основные отличия данных учреждений от школы, которые проявляются в свободе выбора деятельности и педагога, обучающей программе. Существенным формирующим началом стало творчество в разнообразных его проявлениях; особенные взаимоотношения сотворчества сложились между ребенком и учителем; позволяет ребенку получить начальную профессиональную подготовку.

Ретроспективное исследование развития дополнительного образования детей в России позволяет обнаружить существенные направления формирования учреждений дополнительного образования детей в России [7].

Первой направленностью можно назвать изменения целей деятельности учреждений дополнительного образования детей в России, в повышении качества образования. Ранее целью данных учреждений было привлечение большого количества детей и организация условий для их формирования. В настоящее время учреждения дополнительного образования детей осуществляют целый комплекс социально-педагогических и образовательных целей. Наряду с образовательными задачами, создаются условия для личностного формирования, самореализация и укрепление здоровья учащихся; воспитание общей культуры учащихся; увеличение квалификации педагогов и управленцев; социальная поддержка детей, родителей и сотрудников. Увеличивается спрос детей, родителей, общественных организаций на виды деятельности учреждений дополнительного образования детей. Появляются центры профессиональной стажировки педагогов, исследовательские лаборатории, что приводит к росту отделов и служб.

Второй направленностью развития учреждений дополнительного образования детей является расширение содержания работы подразделений соответственно с государственными запросами и общественным заказом на образование. Учреждения дополнительного образования детей рекомендуют различные направления деятельности, такие как художественное, вокальное, хореографическое, спортивное, туристическое, краеведческое и др.; исполняют образовательные, социально-педагогические, психологические, досуговые, методические функции; прорабатывают разнообразные виды программ (авторские, адаптированные, модифицированные, типовые программы для талантливых детей).

Третья направленность проявляется в расширении структурных подразделений и должностей, осуществляющих предназначение дополнительного образования детей. Функции управленцев выполняют директора учреждения и их заместители по различным направлениям деятельности (главные бухгалтеры, художественные руководители объединений, режиссеры и др.). Педагоги дополнительного образования, педагоги-организаторы, психологи, социальные педагоги осуществляют педагогические функции. Библиотекари, бухгалтеры, техники, лаборанты исполняют учебно-вспомогательные функции.

В структуре учреждений дополнительного образования детей в настоящее время появляются многообразные структурные элементы - студии, школы, клубы, мастерские, лаборатории и другое. Формирование структуры реализовывается также за счет организации органов государственно-общественного управления.

Переход от линейно-функциональной организационной структуры к адаптивной структуре с матричными и проектными элементами является четвертой направленностью. В структуре учреждений дополнительного образования детей продолжается организация исследовательских групп; педагогических, художественных советов, аттестационных, балансовых комиссий, и прочих образований.

Пятой направленностью является увеличение приспособлений самоорганизации и саморазвития учреждений дополнительного образования детей. Для учреждений дополнительного образования детей присущим является организация советов, комитетов, комиссий, объединений по различным видам деятельности. К ним относятся педагогический совет, аттестационная и балансовая комиссия, творческие лаборатории, где участниками могут быть дети и родители, педагоги, психологи, методисты. Данные органы сами могут решать некоторые вопросы управления и следить за процесса- 
ми их формирования.

Систематическое отслеживание и совершенствование итогов деятельности учреждений дополнительного образования детей, является шестой направленностью.

Увеличение внешних связей, появление в структуре элементов, которые обеспечивают открытость учреждений дополнительного образования детей, считается седьмой направленностью. Учреждения дополнительного образования детей все часто осуществляют партнерские контакты с различными школами, детскими садами, учреждениями дополнительного образования детей, с высшими учебными заведениями, с больницами, домами-интернатами, спортивными федерациям и прочими. Вследствие этого, в структурах появляются отделы или специалисты, которые обладают функциями информационного обеспечения учреждений дополни- тельного образования детей.

Таким образом, в области дополнительного образования детей создаются особые возможности для формирования образования в целом, для расширения доступа к глобальным знаниям и информации, обновления его содержания, согласно с задачами перспективного формирования страны. Данная область становится инновационной площадкой для отработки образовательных моделей и технологий будущего. Дополнительное образование определяется как ведущий тренд формирования образования в XXI веке. Для более совершенного функционирования системы дополнительного образования необходимо разрабатывать единую модель центров дополнительного образования, обеспечивающих учет интересов всех участников образовательного процесса.

\section{ЛИТЕРАТУРА}

1. Конституция Российской Федерации (принята всенародным голосованием 12.12.1993) (с учетом поправок, внесенных Законами РФ о поправках к Конституции РФ от 30.12.2008 № 6-ФК3, от 30.12.2008 № 7-ФК3, от 05.02.2014 № 2-ФК3, от 21.07.2014 № 11-ФК3).

2. Федеральный закон от 29.12.2012 N 273-Ф3 (ред. от 01.03.2020) 06 образовании в Российской Федерации // Собрание законодательства РФ, 31.12.2012, N 53 (ч. 1), ст. 7598

3. Типовое положение об образовательном учреждении дополнительного образования детей / [Утверждено постановлениями Правительства РФ № 233 от 7.03.1995г. и № 212 от 22.02.1997г.] // Вестник образования. - 1997. - №6. - С. 12.

4. Голованов В.П. Становление и развитие отечественной системы дополнительного образования детей: исторические уроки и задачи / В. П. Голованов // Внешкольник. - 2008. - № 5. -С. 1418.

5. Евладова Е.Б., Логинова Л.Г., Михайлова Н.Н. Дополнительное образование детей: уч. пособ. для студ. учрежд. сред. проф. образ. - М. : Гуманитарный издательский центр ВЛАДОС, - 2002. - 348 c.

6. Казанская Г.А. Становление образовательно-воспитательного процесса советской школы в 20-е годы XX века / Г.А. Казанская // Педагогический профессионализм в современном образовании: мат-лы ІІІ Межд. науч.-практ. конф. (Новосибирск, 2122 февр. 2007 г.) / под науч. ред. Е.В. Андриенко. Новосибирск: Изд-во НГПУ, - 2007. - С. 389-396.

7. Кузьминов Я.И. Российское образование: достижения, вызовы, перспективы. - М.: Издательский дом Высшей школы экономики. - $2019 .-280$ с.

8. Матвеева М.А. Удовлетворенность детей качеством образовательных услуг в учреждении дополнительного образования. // Молодой ученый. - 2019. № 1 (239). - С. 178-180.

9. Медынский Е.Н. Энциклопедия внешкольного образования. - М.: Государственное издательство, - 1923. - 123 с.

10. Могутова П.П. Дополнительное образование детей как фактор формирования самооценки. // В сборнике: Образовательная система: новации в сфере современного научного знания сборник научных трудов. Казань, - 2019. - С. 173-179.

11. Носова О.В., Волокушин В.М., Шишов И.И. Саморазвитие личности учащихся в условиях дополнительного образования детей. // В сборнике статей Международной научно-практической конференции. - 2019. - С. 67-69.

12. Прохорова Л.Н. Воспитательный потенциал дополнительного образования детей. // В сборнике: Социальное воспитание как целевая функция дополнительного образования детей сборник научных статей международной научно-практической конференции. - 2019. - С. 146-149.

13. Терентьева А.И., Люгаева О.С. // Роль дополнительного образования детей В современном обществе. // В сборнике: Цели и ценности современного образования Материалы Всероссийской научно-практической конференции с международным участием. Отв. ред. В.э. Черник. - 2019. - С. 110-114.

14. Трубников А.П. Сто лет дополнительному образованию детей: опыт, проблемы, перспективы. // В сборнике научных статей международной научнопрактической конференции. -2019. - С. 13-19.

15. Фролова Г.И. Организация и методика клубной работы с детьми и подростками. - М. : Просвещение. - 1986. - 160 с.

(c) Цяо Ланьцзюуй (qiaolanju@gmail.com). 